\title{
Syed Mujtaba Ali's Deshe Bideshe: an Indian's perspective on Afghanistan
}

\author{
Abhijit Ghosh \\ Assistant Professor of English, Balagarh B. K. Mahavidyalaya, Hooghly, West Bengal. \\ Email:abghosh2002@yahoo.co.in
}

\begin{abstract}
Syed Mujtaba Ali's Deshe Bideshe, first published in 1948, is a travel account of enduring popularity based on his experiences in Afghanistan during the years 1927 to 1929. In this reading I wish to concentrate on the distinctive quality that sets it apart from the typical travel writing of the age produced by the colonial encounter. Mujtaba Ali's experience of colonialism in India combined with his profound sense of history makes him uniquely capable of providing a glimpse of Afghanistan during a period of social and cultural transformation. His portrayal of the Afghan identity in confrontation with external colonial forces and internal upheaval is not only invigorating but also challenging because it is not directed at demystification or categorization as in colonial texts aiming to comprehend the oriental. His colonised self-consciousness finds in the independent Afghan a cause to celebrate and thus allows us to explore his work as a postcolonial text. According to Justine D. Edwards and Rune Graulund, postcolonial travel writing "subverts both colonial claims to truth making, as well as the nexus between travel and domination" (Postcolonial Travel Writing: Critical Explorations, 3). Therefore, while a typical European travelogue like Robert Byron's The Road to Oxiana (1937), written a few years after Ali's visit provides an unabashed view of Afghanistan as a historical artefact requiring British protection, a colonised Indian's account of Afghanistan hits out at the "nexus between travel and domination" and seeks to initiate a south-south dialogue inspired by the hope of regional collaboration.
\end{abstract}

Keywords: travel narrative, Afghanistan, colonialism, postcolonial text, Robert Byron

The troubled history of Afghanistan has made the country the perennial object of curiosity and antagonism and interestingly, it is usually the image of the country projected by Western 'imperial' eyes that the rest of the world sees and remembers. Today it may be looked down upon as the global terror hub, but the country was not always like it is today and one of the reasons for the contemporary relevance of Mujtaba Ali's book is its portrayal of a different Afghanistan. Syed Mujtaba Ali's Deshe Bideshe, first published in 1948, is a travel account of enduring popularity based on his experiences in Afghanistan during the years 1927 to 1929. The Western intervention into Afghanistan started with the British in 1838, but when Ali visited Afghanistan, it was still a place with anticipations of a different future. Perhaps the abiding interest of Deshe Bideshe rests on the possibility of imagining an alternative space untainted by imperialism. Probably this distinctive portrait of the country, so different from popular perceptions of our time, prompted the recent translation of Ali's book (In a Land far from Home: A Bengali in Afghanistan) by Nazes Afroz in 2015. Ali had gone to Kabul to serve as a Professor in the newly reformed education system under King Amanullah and had resided there as a part of a small Western community of

(c) AesthetixMS 2020. This Open Access article is published under a Creative Commons Attribution Non-Commercial 4.o International License (http://creativecommons.org/licenses/by-nc/4.o/), which permits non-commercial re-use, distribution, and reproduction in any medium, provided the original work is properly cited. For citation use the DOI. For commercial re-use, please contact editor@rupkatha.com. 
professors and diplomats from Russia, India, France, Italy and Germany. Ali's book, therefore, can be read as a document exploring a 'contact zone' revealing a half-forgotten episode of Afghan history and nationalism with the British and the Russians playing political games, scarcely disguising their imperialistic ambitions. Mary Louise Pratt defines such social spaces as 'contact zones':

The possibilities and perils of writing in 'contact zones', social spaces where disparate cultures meet, clash and grapple with each other, often in highly asymetrical relations of domination and subordination - like colonialism, slavery, or their aftermaths as they are lived out across the globe today. (Pratt,1992, p. 4)

Mujtaba Ali's delightful prose style and keen sense of humour might be the reasons behind the enduring appeal of this travel account, but in this reading I wish to concentrate on the distinctive quality that sets it apart from the typical travel writing of the age produced by the colonial encounter. If we compare Ali's book to the traveller Robert Byron's account of his visit to Afghanistan recounted in his book The Road to Oxiana (1937) we find some interesting differences. Byron had visited Afghanistan in 1933, about five years after Mujtaba Ali. The Civil war and siege of Kabul that had forced Ali to return had ended long ago with the killing of Habibullah Kalakani or Bacha-ye Saqao but the country's scarcely regained political calm was shattered again due to the assassination of King Nadir Shah in 1933. The political turmoil in the country evoke contrasting responses from Ali and Byron. Mujtaba Ali was concerned at the fragile political condition of the Afghan nation, and pained by the defeat of King Amanullah and the consequent retreat of his modernist reforms. Robert Byron, on the other hand, is undeterred by the assassination of the King, and hardly stops to notice the socio-political condition around him unless faced by personal inconvenience or hindrance. If Ali laments for the inconsistency of the developmental efforts and instability of the political affairs, Byron grieves for the lost architectural treasures of Afghanistan. Whereas Mujtaba Ali looks at the present and envisions the social and cultural future of the nation, Byron's gaze is resolutely turned to the past. Ali is concerned with the people he meets, fondly describing their manners and opinions; Byron, on the other hand, is not at all concerned with the people he encounters. Byron looks at Afghanistan as an oriental treasure house of art, and conceives of his vocation as the archetypal explorer. According to Justine D. Edwards and Rune Graulund, postcolonial travel writing "subverts both colonial claims to truth making, as well as the nexus between travel and domination" (2010,p. 3). Byron's writing reveals this nexus by the way he asserts his claim over his domain, by his unhesitating faith in his privileges as an European, his domineering attitude towards the local people and his impatience at obstacles in his path.

Deshe Bideshe ruptures the nexus between travel and domination perhaps because it is a colonised Indian's account of Afghanistan. Ali's experience of colonialism coupled with his faith in a fraternal bond with fellow Orientals gives him a distinct perspective on Afghanistan. Ali's portrayal of the Afghan identity in confrontation with external colonial forces and internal upheaval is not only invigorating but also challenging because it is not directed at demystification or categorization, as in colonial texts aiming to comprehend the oriental. The anthropological vision was, more often than not, associated with an imperial agenda of colonisation. Ali does not wear the ethnographer's glasses that seek to survey, objectify and classify, a process which inevitably leads to essentialism. Neither does he have the European traveller's superior air, like Byron, surveying his pastoral ruins with pleasure and gratification. Ali's portrayal of Afghans, their habits, character and customs is sympathetic and mixed with witty comparisons and associations between languages, customs and religions. In Byron's account, the Afghans are so reduced to 
insignificance that they often seem to be invisible. Ali's inimitable humour, denial of value judgements, his genial, warm and lively portraits of Afghans whom he encounters, challenges and rejects any stereotypical representation of the Afghan.

When the author inquires about the theory that considers Pathans to be one of the twelve tribes of Israel, an Afghan professor wittily replies that they would have been proud of such an originary myth thirty years ago, but at present they consider themselves to be the descendents of Aryans according to the prevailing fashion (pp. 22-23). The ordinary Afghan, according to the author's Afghan friends, is no doubt violent, but not violent by nature: it is rather the lack of fertile lands, and their indisposition for business that is the reason for their opting for the army or their recourse to robbery. The Afghan is intensely vengeful, especially in matters of honour, and he values his gun above anything else. On the other hand, he absolutely loves companionship and freewheeling conversation full of stories and anecdotes. The independent spirit of the Afghans impresses the author so much that he praises it repeatedly. The Afghan is proud, brave and belligerent, but is also very much humane in his kindness, generosity and simplicity. Compared to the cunning British, the Afghan is simple, even naive. In Ali's account, the descriptions of the Afghan character are offered by Afghans themselves on various occasions, revealing their open, unreserved natures. In Robert Byron's book, however, we find the author passing his judgement on Afghans barely hiding his scorn for them:

They carry rifles to go shopping as Londoners carry umbrellas. Such ferocity is partly histrionic. The rifles may not go off. The physique is not so impressive in the close-fitting uniform of the soldiers. Even the glare of the eyes is often due to make-up. But it is a tradition; in a country where the law runs uncertainly, the mere appearance of force is half the battle of ordinary business" (Byron, p. 88).

Byron's also appears rather brash in describing their dress, unabashedly exoticising the Afghan's appearance doubtless with a view to entertain his European audience:

The townsmen too sport an occasional waistcoat in the Victorian style, or the highcollared frockcoat of the Indian Mussulman. But these importations, when accompanied by a turban as big as a heap of bedclothes, a cloak of parti-coloured blanket, and loose white peg-top trousers reaching down to gold embroidered shoes of gondola shape, have an exotic gaiety, like an Indian shawl at the Opera. . . . The most singular costume is that of the neighbouring highlanders, who sail through the streets in surtouts of stiff white surge, dangling false sleeves, almost wings that stretch to the back of the knee and are pierced in patterns like a stencil. Now and then a calico bee-hive with a window at the top flits across the scene. This is a woman. (Byron, pp.87-88).

Byron is not an exception. Most European travel narratives seek to exoticize the places and people they encounter. This is often guided by the author's putting on the guise of an explorer, discovering the 'strange' customs and practices of other peoples and trying to interpret them. The desire of 'knowing' the 'other' is paramount in western narratives of travel. There is in Ali's writing, however, a reorientation of emphasis that may be said to operate in conventional travel writing. In Deshe Bideshe exoticism is replaced by familiarization. Ali hopes to familiarize the Afghan to his audience and therefore his writing is characterized by the absence of any invented aura of strangeness.

Mujtaba Ali's experience of colonialism in India combined with his profound sense of history makes him uniquely capable of providing a glimpse of Afghanistan during a period of social and cultural transformation. His commentary on the history and politics of the time 
becomes a crucial document and seems to be equally significant to his descriptions of Afghan character and territory. The period of Ali's visit coincides with the historical epoch known as the 'great game', when the British and the Russians vied for control of Afghan territory and politics. The British wanted to use Afghanistan as a buffer state to protect British interests in the Indian subcontinent from a presumed Russian invasion, and we find hints of British anxiety about the a Russian invasion in India (p.23, p.36). Ali's account ends with and due to the rebellion of tribals led by Bacha-e Saqaw in 1928, the ensuing Afghan civil war and the end of Ammanullah's reign. The articulation of the days of suffering that Ali witnesses in Kabul, especially his own experience of near starvation during the time is quite vivid. Ali regrets his inability to meet the Afghans living in the villages, the Afghan tribal population, and laments the lack of means to understand their practices and economy. However, he deplores the extreme poverty and lack of economic resources of the villages, the taxation and the resultant vicious cycle of economic backwardness that fuels tribal rebellions in different parts of the country. Umaprasad Mukhopadhyay, another famous Bengali traveller, travelling to Khyber Pass in the same year as Mujtaba Ali in 1928, had the good fortune to visit an Afridi village. He had journeyed only up to the border of British India, and not into Afghanistan, yet his account remains interesting because it not only provides a vivid description of the Afridi village but also an impressive sketch of his journey by train from Peshawar to Landikotal. Umaprasad describes the austere setting of the Afridi village, bordered by barbed wire fences and high walls, and guarded by rifle slinging Afridis from a watch tower. He notes their spirit of independence, their indomitable and fierce appearance, coupled with an exceedingly hospitable demeanour in spite of the obvious poverty of their lives.

The self-consciousness of a subjugated race finds in the independent Afghan a cause to celebrate. Mujtaba Ali's emphasis on the spirit of nationalism in Afghanistan allows us to explore his work as a postcolonial text. There is a feeling of exuberance in experiencing the freedom of Afghanistan coupled with a keen sense of sorrow at being the representative of a colonised nation. Afghanistan often becomes a mirror, where the author's thoughts and feelings for his own country are reflected. Afghanistan and its resistance to colonialism becomes a comparative framework for India. The author's antagonism towards the British is reiterated in his reflections on Afghanistan's recent history, especially in his comments about the third Afghan war. The author's experiences here, especially incidents and encounters become markers for his reflections on the colonial scene in India. The market in Kabul, for example, leads him to reflect on the destruction of the muslin silk industry of India as a result of colonial policy. The author's hatred for colonial authority is evident in his highlighting of the remarks of an Afghan border official who calls the British animals. The author, suddenly afraid of such a seditious remark, realises that he has just crossed over to independent Afghan territory. Kipling's phrase, "the white man's burden” gets a wholly new interpretation from a fellow traveller of Ali, a man from Kabul whom he befriends during his travel through the Khyber Pass. According to this man, it refers to the unselfish efforts of the white imperial race to eternally prolong the institution of starvation deaths in the poor Orient. And since the poor people of Afghanistan prefer to carry their own burden, passports are denied to the 'deeply religious' Christian missionaries who are over eager to carry the 'burden'. The British however, who are the next in line in their willingness to carry it, are merely tolerated in Afghanistan for diplomatic reasons (p. 42). Ali, in his characteristic humour, compares this newly received wisdom to the gospel of Mark and Mathew! He compares the plundering British to some everlasting Timur or Nader Shah, who have ravaged the subsequent history of India and Afghanistan. Quite significantly, he invokes the half-forgotten history of King Mahendraparatap who had unsuccessfully campaigned for an Afghan invasion by King Habibullah against British India during the turmoil of the First World War. 
If there is an unmistakable sense of pride in Afghanistan's cultural indebtedness to India, Ali also takes pains to illustrate India's indebtedness to the country of the Ghaznavid Al-Biruni. In his brief recourse to the history of Afghanistan, he attempts to highlight the indelible connection between the histories of India and Afghanistan since the time of Alexander. Ali considers Afghanistan as the link between Greece and India on the one hand, and between Iran or the ancient Persia and India on the other, for it is through this land that Greek and Persian art and architecture travelled to India. After Alexander the Mauryas made Afghanistan a part of India. It was during this time that Buddhism spread in Afghanistan. The Kushana period, and especially the reign of Kanishka, provides evidence of the blending of Greek, Afghan and Indian art. During Huen Tsang's visit to Kabul in the $7^{\text {th }}$ century, the region had a mixed population of Hindus and Buddhists and the reverberation of the revival of Hinduism in India had reached Kabul. Huen Tsang, Ali insists, had considered Kandahar, Ghazni and Kabul as part of India. Even after the arrival of the Arabs, Hindu Kings held sovereignty over parts of Afghanistan, and their lineage, as illustrated in Kalhana's Rajtarangini, could be traced later in Kashmir. In the eleventh century AlBiruni had travelled to India with Mahmud of Ghazni, and his Tehrik-e-Hind, remains the one of the first and the finest documents on the history, art, culture philosophy and sciences of India. The Ghaznavid period also saw the spread of Persian language and literature, Byzantine and Persian architecture, the practice of writing history and Unani medicine in India; so that Afghanistan became the bridge that connected India to Persia and the Arab lands. The history of cultural interdependency of the nations of India and Afghanistan impresses the author so much that he goes so far as to utter a prophecy divining a greater degree of cultural indebtedness of Afghanistan to India in the future (p. 99). He provides his reasons for envisioning such a golden future, but such a prophecy appears to us rather naive in the light of the tragic history of Afghanistan especially since the 1970 s and the ravages suffered by the country due to the interference of imperialistic forces.

Mujtaba Ali's exploration of Afghan nationalism and the tradition/modernity debate is very significant. In Deshe Bideshe we find the same optimism as in Tagore's travelogue Parosye. Tagore had visited Iran and Iraq in 1932, merely four years after his student Mujtaba Ali. The nationalistic endeavours that he witnesses in Reza Shah's Iran, leads him to contemplate on the contrasting spirit of Europe and Asia: Europe's devotion and mastery of the materialistic sciences and its eventual slavery to the means of its supremacy; Asia's earlier decay and its recent renascence under the influence of Europe. Tagore envisions the birth of a new age in West Asia and is highly optimistic about Asian nationalism. He is effusive about Persian nationalism and the progressive practices and laws introduced by Reza Shah Pehlevi in his travel account on Persia. Mujtaba Ali's visit to Afghanistan had coincided with the last couple of years of King Amanullah's reign, when most of his reformist policies were already underway. Amanullah's reformist zeal had ushered in a decade of great social transformation. He had undertaken to change the traditional ways of Afghanistan to suit the modern age. A lot of the conversations and discussions in the text converge on the effect of the King's reforms and their effects on Afghan society as a whole and their repercussions on his rule.

Ali's admiration for Amanullah is not only due to the latter's valiant campaign against the British in the Third Anglo-Afghan War in 1919 and his establishment of full sovereignty including the right to conduct its own foreign affairs but also because of his goal of modernizing the country. Perhaps Mujtaba Ali's reason for being in Afghanistan is King Amanullah's education policy which seeks to modernise education and training according to Western ideas. Ali is, therefore, openly appreciative of the King's efforts. However, he records the fact that Amanullah's penchant for European norms of educational and social reform did not go down well with the 
conservative forces. There is a lot of debate on King Amanullah's reign and his controversial policies in the pages of the text and Ali more often plays the role of a faithful listener, recording the opinions of the Afghans, rather than providing his own. People like Mir Aslam and Ahmed Ali are critical of the Amanullah's policy and think that his policies are responsible for the frequent rebellions by various Afghan tribes across the country against him. On the other hand there are other Afghans like the border official who dream of a new vibrant Afghanistan under King Amanullah. Similarly, Ali records the divergent opinions surrounding the custom of purdah, but finally seems to endorse Mir Aslam's view that the King and the Queen's stance against the ageold custom was one of the crucial reasons behind the tribal revolt. However, Mujtaba Ali's admiration for the king is countered by his concern at the excesses of the King's reformist zeal: initially when he visits Paghman and then in Kabul, he is pained to see Afghans renouncing their traditional dress to don the dereshi in the European fashion due to the King's decree.

Ali's incorporation of various voices and opinions makes him different from a British traveller like Robert Byron, who is quite brazen in his judgements of the King of Persia (Marjoribanks) and Amanullah and their efforts to modernise Persia and Afghanistan respectively: "Amanullah, the story goes, boasted to Marjoribanks, that he would westernise Afghanistan faster than Marjoribanks would westernise Persia. This was the end of Amanullah, and may like pronouncements long be the end of his successors" (p. 88). Efforts of modernisation that Byron encounters at Afghanistan mostly provoke his irritation. Byron, typifies the Western traveller, who travels to explore and experience "the novelty and pastoral romance" (Byron, p. 270) of the Orient unsullied by modernisation. Afghanistan seems to be a historical artefact to a traveller like Byron, who in all probability expects to have it preserved like a museum. He is extremely derisive of Afghan nationalism:

Poor Asia! Everything boils down to the inevitable nationalism, the desire for selfsufficiency, the wish to cut a figure in the world and no longer be called interesting for the lack of plumbing. ... Afghan nationalism ... goes its way in silence, sometimes sensibly in the direction of public benefits such as roads and posts, sometimes in that of such extravagant eccentricities as the hotel here and the rebuilding of Balkh. (Byron, p. 295)

He is frequently upset and disappointed at hindrances and obstacles due to political reasons and seems to wish for a perpetuity of imperialism: "And it dawned on us, moreover, that the interests of Russia and England in Asia, instead of conflicting as they used to do, have now become virtually the same, particularly with regard to the buffer states between them." (Byron p. 303)

One of most significant achievements of Mujtaba Ali is the creation of heteroglossia, which challenges the dominant monological tenor of European travel narratives. The conversational style of Mujtaba Ali's prose combined with irreverent and iconoclastic humour rebuts and deliberately avoids the voice of authority and therefore denies truth claims for the opinions he expresses, the facts he presents, or the stories he narrates. His style is informal, given to frequent digressions and incredible parallels, and therefore distinct from the serious and exact tone of the western ethnographer which seeks to establish control. The conversational tone becomes very effective because often the information related by the author is provided directly by Ali's interlocutors, so that the authorial voice lacks pretensions of authority, control and truth. The authorial mediation is relegated to the minimum because the author avoids reported speech and directly quotes his acquaintances in the foreign land. By giving scope to a lot of voices, opinions and debates Ali avoids the monologism that is bound to creep into travel narratives where the author is the sole authority for interpretation of a foreign culture. James Clifford in his article 'On Ethnographic Authority' (1983) highlights the need to form complex images of 
diversity to avoid the tendency towards homogenisation: "It is more than ever crucial for different peoples to form complex concrete images of one another, as well as the relationships of knowledge and power that connect them" (119). Providing the analogy of Bakhtin's analysis of the polyphonic novel, he says,

For Bakhtin, preoccupied with the representation of non-homogenous wholes, there are no integrated cultural worlds or languages. All attempts to posit such abstract unities are constructs of monological power. A culture is, concretely, an open ended creative dialogue of subcultures, of insiders and outsiders, of diverse factions. (Clifford, 1983, p. 136)

Mujtaba Ali captures a diverse range of people and their distinctive expressions and opinions. The melange of brilliant portraits in Deshe Bideshe include his servant Abdur Rahman, the Afghan professors and intellectuals Mir Aslam and Dost Mohammed, the Pathan Ahmed Ali, the Russian intellectuals Bogdanov and Demidov, other Europeans who form the community of professors and legation members and minor characters like an Afghan border official, a farmer and so on. Mujtaba Ali succeeds to a great extent in capturing the complexity of the society, politics and culture of the Kabul of his time. The distinctive voice of each person prevents the dominating monological voice of the author from taking over and establishing control.

\section{References}

Ali, M. S. (1948). Deshe Bideshe. Rpt. Syed Mujtaba Ali Rachanabali 9 \& 10. Kolkata: Mitra O Ghosh, 1995 \& 1997.

Byron, R.(1937). The Road to Oxiana. London: Macmillan.

Clifford, J. (1983). On Ethnographic Authority. Representations 2: 118-146.

Edwards, J. D. and Graulund, R.(eds.) (2010).Postcolonial Travel Writing: Critical Explorations. Basingstoke: Palgrave Macmillan.

Pratt, M. L. (1992). Imperial Eyes: Travel Writing and Transculturation. London: Routledge.

Tagore, R.(1991). Parosye. Rabindra Rachanabali. 11. Kolkata: Visvabharati. 